\title{
The Welenrengnge Boat Model: Maritim Character Building of Higher Education in Indonesia
}

\author{
A B. TAKKO BANDUNG \\ Department of Indonesian Literature, Faculty of Cultural Sciences, Hasanuddin University \\ email: abtakko@unhas.ac.id
}

\begin{abstract}
This study is a cultural research using a descriptive qualitative design, namely Maritim character values constituted in the script of Sawerigading Voyage to China which profoundly classified, interpreted, and described. The model used in this study is called the Welenrengnge Boat Model result shows that Welenrengnge can be utilized in order to implement the Maritim character for Hasanuddin University academicians and it has been tested to students at Faculty of Humanities, Hasanuddin University. Based on the scenario, building the maritim character is started by choosing what to hear, see, read, review, discuss, perform and imparted them into someone's personality, in order to change and shape the character of either individually or collectively. Implanting maritim character with the Welenrengnge Boat Model requires considerable time. The experimental research shows that the students generation of 2014 of Indonesian Literature Department of Faculty of Humanities have commenced to build the Maritim character.
\end{abstract}

Keywords: higher education, welenrengnge boat model, maritim character

\section{Introduction}

In paying attention to the dynamics of campus life at various higher educations in Indonesia, it is necessary to set the national character specifically and viscerally. We realize in daily life that there are many problems happen, for instance, in social life, culture, law, etc., as if we do not have a national character. Students should be more focus on themselves in reviewing knowledge, discovering innovations, and being a role model. Unfortunately most of them are unaware of their existence as a student which are unproductive and unscientific in activities and done negative brawling action such as, looting by students and etc. Why those negative thing this happen and who is responsible for them?

Brawling among students often happens in various of higher educations in Indonesia including in Makassar. In Makassar brawling among students had occurred several times: on June 2, 2016 it occurred between the students of Faculty of Engineering and Faculty of Arts and Design of Makassar
State University (Rakyatku.com, 2016). The brawling also occurred at Hasanuddin University in Makassar on December 7, 2015 between Faculty of Engineering and Faculty of Mathematics and Natural Science. And it also occurred at some other higher educations (Kompas.com, 2015).

Zoelva (2014:8-9) in a scientific presentation on the $59^{\text {th }}$ Hasanuddin University's Anniversary stated that higher education is not only encompassing, even prioritizing the identity development and character but also transferring the knowledge and the technology. Activities at the university have been reduced and just filled or complemented in student's brain only, and failed to develop the personal capacity.

The higher the education is not merely an institute which imparts knowledge but also a league for building characteristic values of the nation.Zoelva (2014: 9) asserted that many higher education products involved in a variety of crimes such as corruption, particularly after having succeeded and settling their positions as public figures or

Received: August 22, 2016, Revision: November 14, 2016, Accepted: December 19, 2016

Print ISSN: 0215-8175; Online ISSN: 2303-2499. Copyright@2016. Published by Pusat Penerbitan Universitas (P2U) LPPM Unisba Accredited by DIKTI. SK Kemendikbud, No.040/P/2014, valid 18-02-2014 until 18-02-2019 
politicians. The corruption cases seem never decrease and will enhance continually to the system in a vast range of life sectors. Surprisingly, the investigation reveals that most of the corruptors came from higher education graduates or university products.

Higher education institutions must possess high concerns in accomplishing the case of national character. The management of Hasanuddin University had gathered a group of scholars to hold the National Character Development Workshop to Hasanuddin University lecturers on November 19-20, 2011 at Singgasana Hotel in Makasar. There was a tight controversy, specifically at Commission I (the writer also incriminated the meeting). Eventually, the workshop participants bargained a formulation for character building at Hasanuddin University which has an acronym "Maritim" (humane, sagacious, religious, innovative, sturdy, integrity, and independent).

The seminar and workshop resulted in the formulation of Maritim character which has not yet run maximally, but it was more to discourse level, socialization at the admission of new students and there has been no special program to embody the Maritim character at Hasanuddin University.

Obviously, in embodying the Maritim character program, a model is required. The model which is offered in this paper is the Welenrengnge Boal-Model.

\section{Research Method}

This study examines the manuscript of folklore in South Sulawesi, Indonesia. The manuscript under study was connected to the phenomenon of social life. A manuscript of Sawerigading Voyage in pursuing his dream and love to the land of China was studied. This research was a cultural study using a descriptive qualitative design. The cultural values in the manuscript were described fully and referred to as the character building method.

Some methods and research stages were done to formulate the cultural values in the folklore script of Sawerigading Voyage in pursuing his dream and love to the land of China are as follows: (a) The reading of the script of Sawerigading Voyage in pursuing his dream and love to the land of China was done meticulously and profoundly; (b) Interpreting the meanings of the manuscript. Formulating and finding the values of Maritim character in the manuscript; (c) Finding the values of Maritim character in the manuscript, then connected it to and tested it to the Buginese community in South Sulawesi as the owner of the manuscript. At this stage the researcher made profound observation and in-depth interview to find out whether the Maritim values in the manuscript was compatible with the values practiced in daily life; (d) The next stage was planning and model finding. At this stage the researcher found a model that is Welenrengnge Boat Model. The model was tested in small scale to one class students at the Indonesian Literature Department of Faculty of Cultural Sciences at Hasanuddin University in a lecture of culture course for one semester.

\section{Establishing Maritim Character}

In human life history when he was born until he died, a man always requires the presence of another person in performing and enjoying their life. Relationships between a man and others will influence and shape personal character as a different personality.

Personality is more affected by daily activities. It is not just an activity today, but also the background of habitual life since it has been passed from infancy to adulthood which is difficult to change. Today if someone or a group of people is planning, changing and undertaking a superb activities, a positive character will be produced. Social interaction established in daily life can affect someone's character development. Kohlberg in Al-Alsyar (2010) put emphasis on social interaction and someone's cognitive development in character building. What is always read, seen, perceived, and undergone will be inserted into personality and change and shape the people character either consciously or unconsciously.

Choosing to know and get along with someone based on what she/he read, hear, see, feel and act is suitable with personal ability. It is relevant to Hermani's statement (2014:7) that the self-model has been continuing for many years to turn through the process of training/learning in life. The turning process occurs in our surrounding environments such as homes, schools, workplaces, social media, and network communication. People in our environment such as parents, siblings, extended families, peers, neighbors, and friends can act unconsciously as the turner.

Bandung (2014:93) stated that in 
this era of globalization, people movement was highly rapid and dynamic because the sophisticated information technology has reached various aspects of life, specifically in urban areas. The nonexistence of cultural filter has eroded the politeness of behaving and interacting with humans and faded mutual respect among them. Therefore, designing a model of cultural setting pattern from manuscripts, one of which is the script of Sawerigading Voyage in pursuing his dream and love to the land of China in the form of character values of "Maritim" which will be practiced at Hasanuddin University community is achievable.

The socialization of conveying the Maritim character to the academic community is performed in a broad range of ways such as assembling banners in different strategic places at campus in welcoming the freshmen program.

The best way to change the behavior in character building for adults like students is awareness of self -identity as a man who must behave in good manners, recognize himself and always build communication with himself. The story of Sawerigading voyage to China using Welenrengnge boat shows the Maritim character. Sawerigading as the main figure in the story always reflects, organizes, and recognizes himself and these were implemented so that he was able to conquer and command the universe. A person or group of people can change something if they have the will to change. However, the change occurs if contact, interaction, information, and new knowledge exist.

The comprehension of Hasanuddin University academicians upon the Maritim characters should be enhanced, especially for students. The initial understanding of freshmen in regard to Maritim character should be socialized intensely and profoundly in one semester. At the beginning of semester freshmen are imparted in-depth comprehension with different concepts of human, sagacious, religious, innovative, sturdy, integrity, and independent. In addition, the existence of experts can illustrate the Maritim concepts and shows a number of experiences in various cases. The learning model is encompassed through scheduled lectures, seminars, in depth discussions, film screenings, theaters, dramas, writing scientific papers about the Maritim, and excursion by making regulation and practice during the trip. Students settled in a class of 30-40 people, then they were led to a village to observe the social life of the rural community with the main observation on the Maritim activity at the village community and fellow students then to be continued with intensive interview to public figures. During the probe at night in the field, evaluation and visceral discussion of what have been done during the day was held. The class was divided into seven groups named humane, sagacious, innovative, sturdy, integrity, and independent group. Each group consisted of five people who presented the data obtained during the day. The research and discussion can be designed by a simulation model. The data and results of the discussion were presented and discussed at campus after putting them on paper.

At the next semester, it is hoped that the students can implement the Maritim characters. These stages are called the Welenrengnge Boat Model.

\section{Welenrengnge Boat Model}

The boat was made of a welenrengnge tree used by Sawerigading in his long vayage to China. The result shows that the Maritim character symbols performed in the story can be referred to the formation of national character at Hasanuddin University in particular.

The hull of the boat symbolized religiosity as a foundation in leading various activities. Related to the context, activities at campus must be based on deep religiosity knowledge, have a concept of God, and students practice their own religion. Thus it can shape spiritual intelligence reflecting identity.

In the story of Sawerigading Voyage to China, the submission and obedience to To Patotoe (God) as a determiner of life was described, they scared to break the precept. They obey the rule that comes from God. Culturally, Bugis people in their daily life particularly those in rural areas are highly observant and strict in conducting safety ceremony that they believe to be a disaster if it is undertaken improperly under the ritual stipulations as pointed out by La Cadduma.

The submission to Almighty God narrated in the script narrated such words of We Tanriabeng when separated with Sawerigading since he would get on Bottillangi:

"It was impossible that I did not get on Bottillangi It was created by Datu Patotoe Datu Palinge' arranged our destiny He also managed our mate in Rualette We did not challenge God 
And changed the stipulations of To Palanroe

No attempt to reject To Palanroe (Salim VIII: 140)

In addition Bandung (2014, 72), explained when Sawerigading would sail, he was advised by his father not to live longer in China in order to be glorious in his own country. Tearfully, Sawerigading replied:

That was my lord As the faith of To Palanroe (God) That has been set by Sang Hiyang It is impossible to challenge God. It is about what has been destined to us (Salim VIII: 150).

Every agreement made (vows) ought to comply with the guarantee as an offering to To Patotoe as God. It was conducted to prove their seriousness in undertaking orders as a gratitude for the success of the trip or their affairs. They keep their promise as the replacement of the soul when Sawerigading was grateful because they had arrived safely in China. Sawerigading said:

"It had been the time for you, to Sulolipu to fulfill the debt to pay God for vow as our soul substitution on our salvation through an ocean passed a huge ocean, and because we were inhibited by a battle seven times we could conquer all of them" (Salim VIII:19)

Thanksgiving was always uttered when something was successfully performed like when Sawerigading successfully entered into a chamber of I We Cudai as the aid of cats, miko-miko and meongpalo. When saying goodby to Sawerigading, both said:

To return again to Bottilangi Thank goodness because To Palanroe blessed you You could reach inside the chamber Woman whom you desire" (Salim X: 185)

In real life achieving a unique and special success requires sagacious innovation. The sagacious and innovative characters in the Welenrengnge Boat Model, the researcher placed it in front of the Welenrengnge boat. The advancement of civilization is fully determined by the society's capability in generating wise innovations.

Higher education including Hasanuddin University should become a center for the sophisticated innovations which can be turned and referred to accomplish a broad range of national issues. The campus must be designed to encourage the creation of a number of innovations. The emergence of a number of innovations usually encounters a wide range of deviances. In the manuscript of Sawerigading Voyage in pursuing his dream and love to the Land of China shows that the innovation of woman named We Tenriabeng demolished various arguments of Sawerigading who wanted to marry her. We Tenriabeng was always insisted by Sawerigading to be his wife. A meeting had been held to decide that the marriage of the twin siblings was banned. In challenging the circumstances, We Tenriabeng persuaded Sawerigading to go sailing to China where there was a girl named I We Cudai whose beauty was like her. Sawerigading argued as was found in the script as follows: How is sister We Abeng I wander and sail
There is no more junk lodged me The shiny
junk has been destroyed It has been eaten by
the mussel, I Latiwajo Manurung Gold junk
The Maiogae's braid has been untangled It is
forbidden to cruise the sea It has broken before
hitting by wave Sail cloth is also pulled down
The flagship of a big boat (Salim VIII: By great
wisdom and innovation, We Tenriabeng replied
Sawerigading's argument by saying "cut down
a tall welerengnge tree to be used as a boat to
sail to China to marry I We Cudai.

The story in a dialog between Sawerigading and his twin sister made him intoxicated:

Please mercy on me so that you are aware Think again Voyage to Wugi's land If only junk Ban you to sail to China I show you Lawe Welenreng tree in Mangkutu (Salim VIII: 20)

Human character and integrity in the Welenrengnge Boat Model were placed behind display of the boat. It symbolizes that human dignity is a major consideration to achieve brilliant success. Dignity belongs to whole human beings that should be preserved together and fastened with high integrity, a word with a deed, taro ada taro gau. Mattulada (1995) states that culturally, Bugis people highly respect human's dignity and prestige, sipakatau, sipakalebbi, which means mutual respect and mutual understanding.

On the Welenrengnge Boat Model, the researcher put sturdy and independent in the middle mast of the welenrengnge boat. It symbolizes the struggle to pursue big dreams which require tenacity, perseverance, hard work, and independence. In the story of Sawerigading pursuing his dream and love depicts the sturdiness and independence for Sawerigading to gain his obsession. The huge and deep sea was passed with sturdiness. He was intercepted seven times by valiant pirates but he never be afraid to face his enemies and always won the battle. The Bugis people are 
well known for their sturdiness in wanderings. There are three tips for the Bugis people in wanderings: tip of tongue, tip of dagger, and tip of penis.

\section{Conclusion}

In developing a civilization of higher education character which are humane, sagacious, religious, innovative, sturdy, integrity, and independent, a holistic design model is needed. The reviewer offers a character formation model namely the Welenrengnge Boat Model since the boat had successfully taken Sawerigading with his entourage to China from Bugis. In his voyage across the ocean, they were always successful despite having a lot of challenges during the voyage. This shows the Maritim (humane, sagacious, religious, innovative, sturdy, integrity, and independent) character values.

The assumption underlying the Welenrengnge Boat Model is it imitates one program which runs holistically and showing that the Bugis people possess culture of Maritim character.

The movement of human life should be designed. Higher education does not only provide various kinds of knowledge to students but also needs to design the birth of quality academic culture. One of them is realizing the Maritim character in higher education by adopting the Welenrengnge Boat Model.

The 2014 generation of Indonesian Literature Department, Faculty of Humanities has practiced the Welenrengnge Boat Model in shaping the Maritim character. It involved 33 people at the beginning of the semester. They were imparted in-depth information about the Maritim character through lectures, discussions, and film screenings. Speakers were not only from lecturers but also motivators and successful speaker from outside the campus. At the end of the program, students stayed in Cambang-cambang village in Pangkep regency for three days.

On the way to Pangkep students were divided into seven character groups, namely humane, sagacious, religious, innovative, sturdy, integrity, and independent. Each group studied the Maritim activities well and fellow students and rural community visited the place. Each group made in-depth interview with community leaders about the Maritim and character carried out in daily life. At the end of the day, Each group prepared a paper based on the data obtained during the journey. The paper was presented and discussed at campus.

According to the scenario of stages to achieve the Maritim character to what was heard, seen, read, reviewed, and performed will penetrate each person and can change and shape his/her character. This model is relevant to what Hermani (2014: 16) states that self-model can change dynamically as a result of the accumulation and relationship of experience, stimulus, environment, and inner self. Family education, school, community, friendship, TV, printed media, books, training, and working condition are factors affecting the self-model.

Changing the behavior of someone or a group of people requires a considerable time. However, students who have practiced this Welenrengnge Boat Model qualitatively have shown the behavior of Maritim character. For example, at the beginning of the semester in 2015 there was a student from the 2014 batch would drop out if he was unable to pay his tuition fee. Spontaneously, they collected money from their friends to help this student to pay for his tuition fee. In this globalization era such concern is rarely discovered.

\section{References}

Bandung, A.B. Takko. (2014). The Maritim Character: Sawerigading Fulfilled His Dream and Love. Yogyakarta: Ombak.

Hermani, Nopriadi. (2014). The Model. Yogyakarta: IKKJ Publisher.

Kompas Com. (2015). Brawl: Unhas Students Damaged Their Own Campus.

Mattulada. (1995). History of the Society and Culture of South Sulawesi. Makassar: Hasanuddin University Press.

Rakyatku.Com. (2016). The Brawl between Students of Enginering and Students of Faculty of Arts of Makassar State University.

Salim, Muhammad. (1993). Transliteration and Translation of I La Galigo. Vol. 1-12.

Zoelva, Hamdan. (2014). The Role of Higher Education in the Establlishment of National Character. Paper of Scientific Presentation on the 58th Anniversary of Hasanuddin University. 